\title{
Coverage of Neighbouring Broadcasting System using Efficient Activity Flow Control
}

\author{
Mohanraj, Hema.R, Hemalatha.B.
}

\begin{abstract}
Although more than 10 years have elapsed from the proposal of Spatial Radio Value system, in these years the analysis was based around evaluation in order to update the convenience of flexible braking for versatile philosophical radios specially built.In versatile specially appointed systems (MANETs), the system topology changes as often as possible and eccentrically because of the subjective portability of hubs. This element prompts successive way disappointments and course reproductions, Which creates an increase in control friction influence course disclosure can't be dismissed. Consequently, it is basic to lessen the overhead of course revelation in the outline of steering conventions of MANETs taking into account.Here we concentrates on a novel steering convention in light of probabilistic rebroadcast and neighbor scope data got utilizing Cognitive radio worldview toward decrease and directing above .Cognitive Radio is a late worldview that goes for added adaptable besides proficient utilization of radio range. It permits remote radios to deftly get to partitions of whole radio range with no unsafe impedance to authorized clients. This joined methodology empowers to give better execution of steering in portable specially appointed Networks and effective use of Radio Spectrum.
\end{abstract}

Keywords : Mobile Ad Hoc Networks, Neighbor Coverage, and Network Connectivity, Cognitive Radio, Probabilistic Rebroadcast, Routing Overhead.

\section{INTRODUCTION}

In Mobile Ad hoc Network (MANET) the hubs can get the administration utilizing arbitrary versatility model to convey one another In the scheme, man. There is no unified network administration[1]i.e. No base station administration to a flexible hub ; because of high portability in system join disappointment and the braking path can not always be characterized by the data transmission, so the indignity of the data and the rejection of the manner are major problems in MANET.Dynamic steering prompts ill-advised neighbor choice to achieve destination.

TTelevision is a major and effective data relocation scheme for the disclosure of courses, email identification and countless other method presidencies in informal applications. When data media has a number of wins of concern, it also creates a number of problems, such as the display storm problem, that is represented by over-transmission, effect, and dispute.

Revised Manuscript Received on August 22, 2019.

Mohanraj Assistant Professor, Department of Electronics And Communication Engineering,, Bharath Institute of Higher Education and Research, Chennai, India. dspmohanraj@gmail.com.

Hema.R, Assistant Professor, Department of Electronics And Communication Engineering,, Bharath Institute of Higher Education and Research, Chennai, Indiahemrbujradha@gmail.com.

Hemalatha.B, Assistant Professor, Department of Electronics And Communication Engineering,, Bharath Institute of Higher Education and Research, Chennai, India. contacthemab@gmail.com.
Why do you need to re-broadcast? In MANET, the hub forwards the rebroadcasting bundle in the light of the current hub, which did not receive the display signal, there is a rebroadcasting package, which allows the administration to adopt the remaining hub in the steering unit. [1]. It essentially covers The neighbor's vibrancy for braking, which results in a reduction in repeatability over re-TV. In order to improve the $\mathrm{TV}$, we can limit the amount of rebroad casting in the broadcast[2 ]. Simulcast postponement characterizes the neighbor scope learning in system [3], keeping in mind the end goal to reinforce the system network, television neighbors ought to get Bundle RREQ[2 ] This reduces the quantity of streams of the information transfer RREQ packet.. [3].

To find the course superior to anything TV philosophy, rebroadcasting is finished with the assistance of neighbor information systems. Considering the ultimate objective of a viable abuse of neighbor-wide data, a new rebroadcast delay and an availability variable to give the hub thickness adjustment is figured. This NCPR convention does not concentrate on range utility proficiently.

\section{A.Emotional Radio Routing:}

The idea of Spatial Radio Cabling is utilized here.distinguishing substantial technique for quicker transmission of rebroadcasting bundles.

Devices with emotional limits can be sorted out to make Cognitive Radio Networks (CRNs), which are starting late getting vitality as attainable compositional responses for area the compelled range availability and the inefficiency in the range use [8].

The reference system model reported in Fig. 1 highlights auxiliary gadgets which share distinctive range groups (or SOPs) with essential clients. A few range groups (1. . M) May happen through particular breaking points $\mathrm{C} 1, \mathrm{C} 2, \mathrm{CM}$, and the SUs may require different viewpoints of the available range. Customarily the PUs is acknowledged still while the SUs may contrast their situation previously and in the midst of a transmission. 


\section{Coverage of Neighbouring Broadcasting System Using Efficient Activity Flow Control}

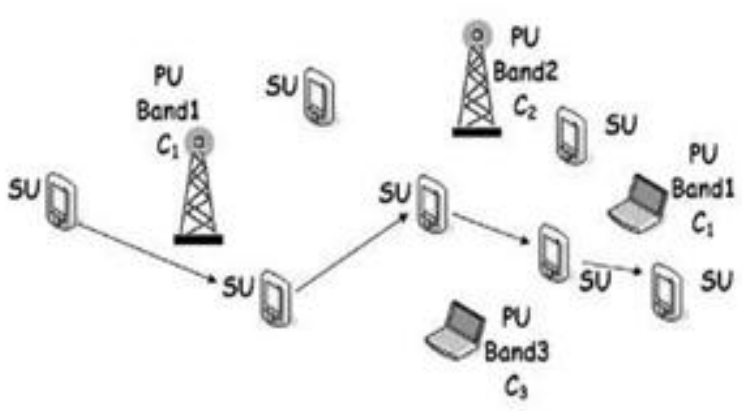

Fig 1: Knowledge management in cross-jump Mobile cognitive ad hoc system

\section{B.Adjustment of Cognitive Radio for neighbor recognizable proof:}

A A typical methodology of including Cognitive radio idea into inserting so as to steer convention is range related data, for example, range opportunity (SOP), directing control parcels. In the course disclosure, this range related data Is glommed to control parcels For instance, the basis hub might embed its range connected data on rreq bundles. At the point when the middle of the road hubs forward the rreq bundles, they likewise incorporate their own particular range related data. At that stage, the target hub would normally get a opportunity to do so. choose the range band to be utilized for information exchange. It doles out the range, embodies It is in rrep, and hands it back to the target location. In like manner, halfway hubs that get RREP dole out the range groups (Figure 2). From now on, on RREQ and RREP sending, the packages are getting greater in size with simultaneousness with the bounce or division between the source and goal.

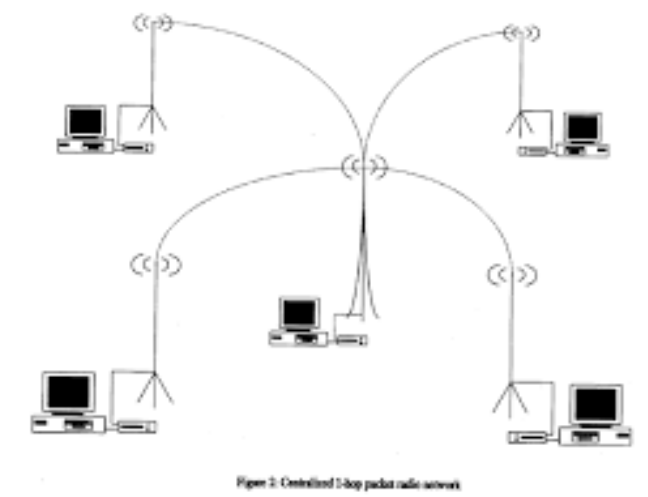

Fig 2: Presence of range occasion into the RREQ and selected choice group into the RREP tracts.

\section{II.RELATED WORKS:}

The steering overhead happened as a result of the dispersal of directing control parcels, for example, RREQ bundles can be entirely tremendous, particularly when the system topology much of the time changes. Customary on-interest steering conventions create a lot of directing movement by aimlessly flooding the whole system with RREQ bundles amid course revelation. As of late, the issue of lessening the steering overhead connected with course disclosure and upkeep in on interest directing conventions has pulled in expanding consideration. [14-20]
Huang[10] suggested a method for potently changing the Hello clock and the Timeout clock as stated by the system states. For example, in a high versatility system (with incessant transformation of the neural networks), it is attractive to use small values for clocks to quickly identify the system's adjustments. Again, in a low versatility scheme where the structure stays constant and with few modifications, the comprehensive quality of the clocks is more convincing to reduce the overhead. Keeping in mind the end goal to choose whether the portability of the system is high or low, we utilize a basic approach to rough continuously of the connection alteration rate. The lessening in overheads is astoundingly cultivated with the noteworthy cost of insignificantly growing the pace of fall in data advancements. While the heap of wiped out fortune increments by about $1 \%$, the wastefulness diminishes by $40 \%$.Ould-Khaoua[11 ] suggested a new deterministic practice disclosure approach called Adapted deterministic practice discovery(AP) and Improve Adapted deterministic scheme disclosure (EAP)

locations the telecast storm issue in the current on - interest directing conventions. The taking so as to send likelihood is dictated into record about the neighborhood thickness of the sending hub.

So as to diminish the steering overhead without debasing the system throughput in thick systems, the sending likelihood of hubs situated in meager zones is set high while it It is laid low at centres in dense distances. EAP-AODV reduces fixed costs by 71 per cent when AP-AODV reduces operating costs by 55 per cent.Aminu[12] Suggested a simulcast probability capability that would register the assessment of the package address with some important re-enactment variables (i.e. system structure size, transmitting range and number of center points) to decide the fitting communicate likelihood for a predefined center point. The rebroadcast probability of a center is prepared in light of these parameters. Contrasted with alternate plans, reproduction results have uncovered that counter Function accomplished unrivaled spared rebroadcast (around 20\% superior to anything its nearest Rival, i.e. cross-base plan, in a dense scheme) and finish-to-end delay (around 26\% higher than any post-base plan in a dense scheme) without delay. giving up achieve capacity in medium and thick systems.

Al Aamri [13] proposed another steering convention for Ad hoc systems, approached interest Tree-based Routing Protocol (OTRP). This convention consolidates the thought of bounce by-jump steering, for example, AODV with an effective course revelation calculation called Tree-based Optimized Flooding (TOF) to enhance versatility of Ad hoc systems when there is no past information about the destination. To accomplish this in OTRP, course revelation overheads are minimized by specifically flooding the system through a constrained arrangement of hubs, alluded to as spreading hubs.

\section{III.NEIGHBOUR COVERAGE BASED PROBABILISTIC REBROADCAST USING INTELLECTUAL RADIO PARADIGM:}

This paper concentrates on enhancing which consolidates both neighbor scope and 
probabilistic strategies. The enhancing instrument concentrates on distinguishing chose set of neighbors taking into account range accessibility for speedier transmission of bundles and subsequently enhancing the effectiveness and execution of the convention. To successfully

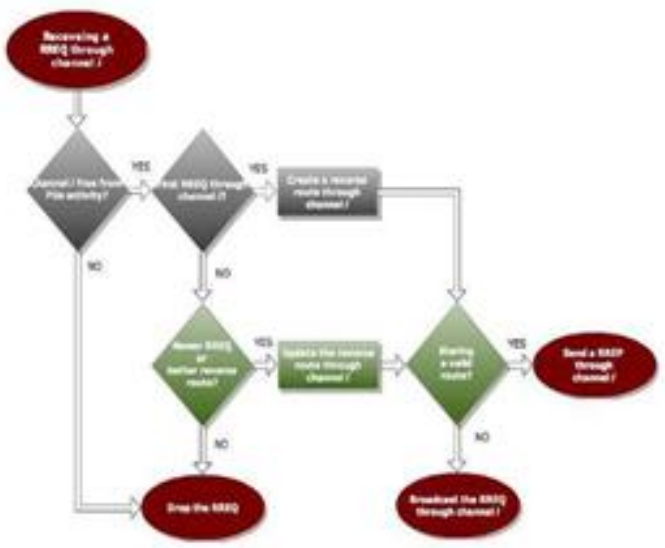

Fig 3: RREQ Flow Diagram

\section{IV.CONCLUSION:}

Versatile specially appointed channels (MANETs) include a lot of compact centers fit for giving a set facilities. Broadcasting is a basic and efficient system for the dissemination of information in the exploration of routes. But it creates the issue of the simulcast storm. To decrease the issue, route exploration methods have been proposed for the layout of routing protocols with excellent results and less operational costs..This perceived neighbor set is utilized as an uncovered neighbor list in the probabilistic simulcast procedure, reducing load propagation and further improving protocol efficiency.

\section{REFERENCES}

1. Kongkham, D. \& Sundararajan, M. 2019, "Distributed wideband sensing method for faded dynamic spectrum access", International Journal of Innovative Technology and Exploring Engineering, vol. 8, no. 10 , pp. 4309-4312.

2. Balaji, S., John Paul Praveen, A. \& Mohanraj, R. 2019, "Recognizable proof and analysis of palm print in biometric authentication system using bayes techniques", International Journal of Innovative Technology and Exploring Engineering, vol. 8, no. 9 Special Issue 3, pp. 1126-1129.

3. Kavitha, G., Priya, N., Velvizhi, R. \& Allin Geo, A.V. 2019, "Paralle computation in correspondence and signal processing", International Journal of Innovative Technology and Exploring Engineering, vol. 8, no. 9 Special Issue 3, pp. 1136-1139.

4. Hema, R., Sundararajan, M. \& Balaji, S. 2019, "Smartphone control robot with automatic firing gun", International Journal of Innovative Technology and Exploring Engineering, vol. 8, no. 9 Special Issue 3, pp. 625-627.

5. Kaliyamurthie, K.P., Sundar Raj, B., Velvizhi, R. \& Shanmugapriya, K. 2019, "Dual band paper substrate CPW antenna for wireless applications", International Journal of Innovative Technology and Exploring Engineering, vol. 8, no. 9 Special Issue 3, pp. 605-608.

6. Geo, A.V.A., Arunachalam, A.R., Michael, G. \& Elankavi, R. 2019 "Evaluating architecture using compact modalities", International Journal of Innovative Technology and Exploring Engineering, vol. 8, no. 9 Special Issue 3, pp. 836-838

7. Theivasigamani, S., Jeyapriya, D. \& Anita Davamani, K. 2019 "Anamoly analyzing and exploring for wireless sensor networks", International Journal of Innovative Technology and Exploring Engineering, vol. 8, no. 9 Special Issue 3, pp. 1116-1118.
8. Jeyapriya, D., Theivasigamani, S., Velvizhi, R. \& Nandhini, P. 2019 "Program detection in wireless feeler networks", International Journal of Innovative Technology and Exploring Engineering, vol. 8, no. 9 Special Issue 3, pp. 1194-1195.

9. Gowri Sankaran, B., Karthik, B. \& Vijayaragavan, S.P. 2019, "Image compression utilizing wavelet transform", International Journal of Innovative Technology and Exploring Engineering, vol. 8, no. 10, pp. 4305-4308.

10. Gowri Sankaran, B., Karthik, B. \& Vijayaragavan, S.P. 2019, "Weight ward change region plummeting change for square based image huffman coding", International Journal of Innovative Technology and Exploring Engineering, vol. 8, no. 10, pp. 4313-4316.

11. Hema, R., Sundararajan, M. \& Balaji, S. 2019, "Smartphone control robot with automatic firing gun", International Journal of Innovative Technology and Exploring Engineering, vol. 8, no. 9 Special Issue 3, pp 625-627.

12. Rangaswamy, K. \& Rajabhushanam, C. 2019, "Congestion control in wireless network using TCP friendly rate control (TFRC)", International Journal of Recent Technology and Engineering, vol. 8, no. 2 Special issue 3, pp. 1598-1602.

13. Tamil Selvan, S. \& Sundararajan, M. 2019, "Performance Parameters of 3 Value 8t Cntfet Based Sram Cell Design Using H-Spice", International Journal of Recent Technology and Engineering, vol. 8, no. 2 Special issue 5, pp. 22-27.

14. Vinoth, V.V. \& Kanniga, E. 2019, "Steganographical techniques in hiding text images - system", International Journal of Recent Technology and Engineering, vol. 8, no. 2, pp. 6535-6537.

15. Saravana, S., Balaji, S., Arulselvi, S. \& John Paul Praveen, A. 2019, "Reliable power quality monitoring and protection system", International Journal of Innovative Technology and Exploring Engineering, vol. 8, no. 9 Special Issue 3, pp. 644-645.

16. Sundaramoorthy, A. \& John Wiselin, M.C. 2019, "Single patch antenna with multiple feed", International Journal of Innovative Technology and Exploring Engineering, vol. 8, no. 9, pp. 1743-1747.

17. Velavan, R., Bharanidharan, S. \& Sheeba, B. 2019, "EMF pollution Causes, effects and protection", International Journal of Innovative Technology and Exploring Engineering, vol. 8, no. 9 Special Issue 3, pp. 1166-1168.

18. Veer, R.A., Arulselvi, S. \& Karthik, B. 2019, "Construction of ensemble square classification approaches in MIMO OFDM", International Journal of Engineering and Advanced Technology, vol. 8, no. 5, pp. 2039-2041.

19. Agitha, W. \& Kaliyamurthie, K.P. 2019, "Improved energy efficient in WBAN using MAC with cloud computing", International Journal of Innovative Technology and Exploring Engineering, vol. 8, no. 8, pp. 2405-2408.

20. Kastro, G.G. \& Wiselin, M.C.J. 2019, "Design and analysis of stub loaded resonator", International Journal of Recent Technology and Engineering, vol. 8, no. 1 Special Issue4, pp. 272-283.

\section{AUTHORS PROFILE}

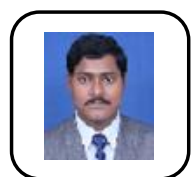

Mohanraj Assistant Professor, Department of Electronics And Communication Engineering,, Bharath Institute of Higher Education and Research, Chennai, India.

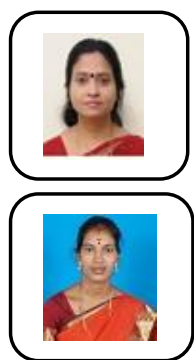

Hema.R, Assistant Professor, Department of Electronics And Communication Engineering,, Bharath Institute of Higher Education and Research, Chennai, India.

Hemalatha.B, Assistant Professor, Department of Electronics And Communication Engineering,, Bharath Institute of Higher Education and Research, Chennai, India. 